\title{
AT3 (Acyltransferase) Gene Isolated from Capsicum frutescens cv. Cakra Hijau
}

\author{
Mohamad Habibi*, Andi Madhihah Manggabarani, Eko Sri Sulasmi, Dwi Listyorini \\ Biology Department, Faculty of Mathematics and Natural Sciences, State University of Malang, Malang, Indonesia
}

\begin{abstract}
Chili pepper is widely used and cultivated by Indonesian people. There are three species of chili pepper, i.e. Capsicum annuum, Capsicum frutescens, and Capsicum violaceum. C. frutescens has a higher economic value due to its pungency and carotenoid content. $C$. frutescens has several cultivars, one of those is C. frutescens cv. Cakra Hijau. This cultivar is resistant against pest and disease and has very high pungency. This special character of chili pepper is capsaicin, its secondary metabolic. Moreover, capsaicin also serves as defense mechanism, antiarthritis, analgesic, and anticancer. This study was aimed to isolate acyltransferase (AT3) gene which encoded capsaicin synthase (CS) enzyme. AT3 gene was isolated through PCR using forward primer 5'-ATG GCT TTT GCA TTA CCA TCA-3' and reverse primer 5'CCT TCA CAA TTA TTC GCC CA-3'. Data were analyzed using DNA Baser, BLAST, and ClustalX. This study has successfully isolated $404 \mathrm{bp}$ fragments of AT3 gene. These fragments are located at 1918-1434 bp referred to AT3 gene from C. frutescens cv. Shuanla. The isolation of upstream and downstream fragments of AT3 gene from C. frutescens cv. Cakra Hijau is undergoing.
\end{abstract}

Keywords: Capsicum frutescens cv. Cakra Hijau, capsaicin, AT3 gene

\section{INTRODUCTION}

Chili pepper is widely used and cultivated by Indonesian people. There are three species of chili pepper, i.e. Capsicum annum, Capsicum frutescens, and Capsicum violaceum [1]. In Indonesia, C. frutescens are the most widely cultivated [2], and is a high economic valued plant for its pungency and carotenoid content [3]. C. frutescens has several cultivars, namely, Sky Line, White Chili, Bara, Cakra Putih, and Cakra Hijau. Cakra Hijau cultivar is resistant to pest and disease, has very high pungency, can be harvested at \pm 80 days, and potentially produces $12.000 \mathrm{~kg} / \mathrm{ha}$ chili fruit [4].

Pungency in chili pepper is caused by capsaicin compound. Capsaicin is only found within Capsicum genus. Capsaicin has been used in medicine and pharmacy as anti-arthritis and analgesic, [5]. It has also been described as the regulator of fat distribution in the body [6], antibacterial [7], and anticancer [8].

\footnotetext{
${ }^{*}$ Corresponding author: Mohamad Habibi

Biology Department, Faculty of Mathematics and Natural Sciences, State University of Malang, Jalan Semarang 5, Malang, Indonesia 65145

E-mail: habib1_m@yahoo.com
}

Several enzymes are involved in Capsaicin biosynthesis. Capsaicin synthase (CS) is the last enzyme which has an important role in capsaicin biosynthesis by condensing vanillylamin with acyl moieties to produce capsaicin. CS also serves as a regulator for the formation of capsaicin [9]. Acyltransferase (AT3) gene is proposed as a gene encode CS enzyme [10]. This statement is supported by Leung[11] who proposesthat AT3 is expressed at placenta and this gene is segregated at $\mathrm{C}$ locus. On the other hand, Kim et al. [12] reported that AT3 co-localized with Pun1 and a 2.5 $\mathrm{kb}$ deletion of AT3 was found to be related to non-pungency in pepper.

The isolation of AT3 gene from $C$. annum [13] and several C. frutescens [14] has been reported. So far, there is no report about AT3 of C. frutescens from Indonesia, and this gene data has not been recorded in Gene Bank. This research was aimed to isolate AT3 gene from $C$. frutescens cv. Cakra Hijau.

\section{MATERIALS AND METHODS}

C. frutescens cv. Cakra Hijau plants were obtained from Balai Pengkajian Teknologi Pertanian (BPTP) Karangploso, Malang, Indonesia. 


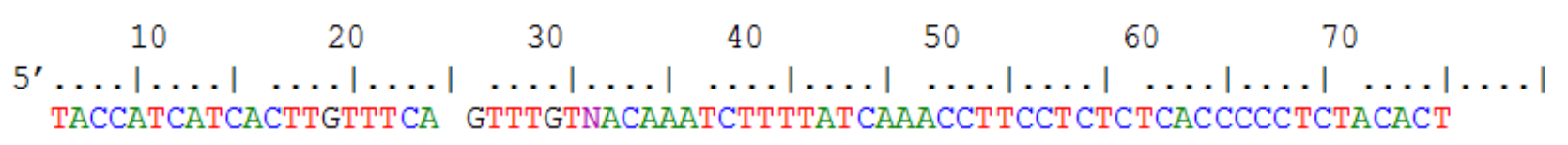

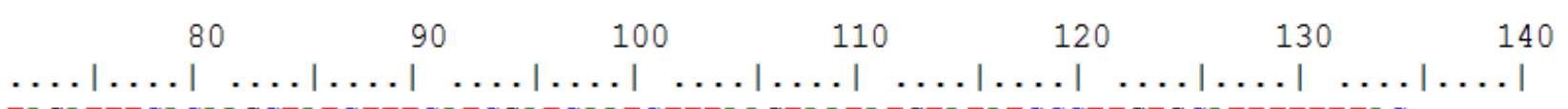

TAGATTTCACAAGCTATCTTTCATCGATCAATCTTTAAGTAATATGTATATCCCTTGTGCATTTTTTTAC

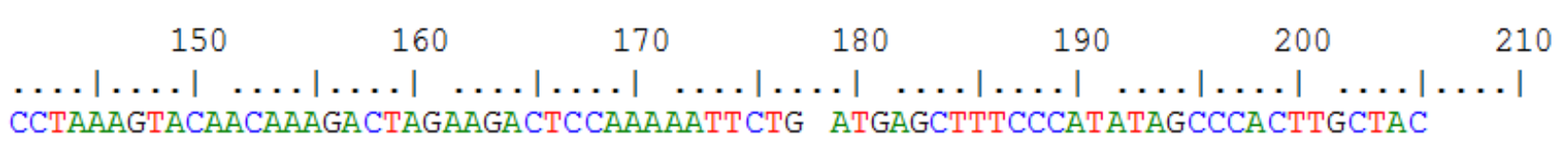

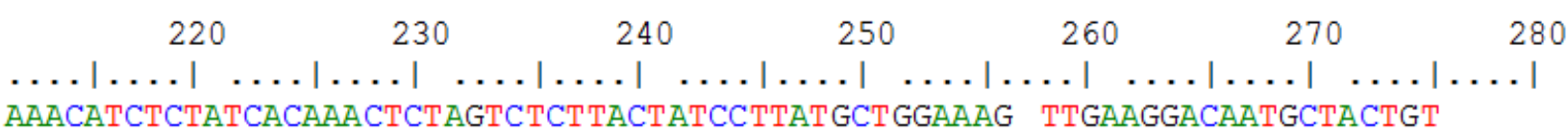

$\begin{array}{rrrrrrr}290 & 300 & 310 & 320 & 330 & 340 & 350\end{array}$

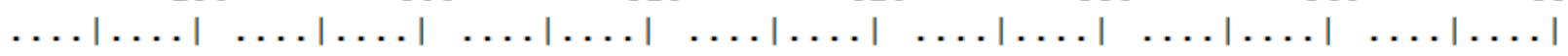

TGACTGTAAC GATATGGGAG CTGAGTTCTT GAGTGTTCGAATAAAATGTTCCATGTCTGAAATTCTTGAT

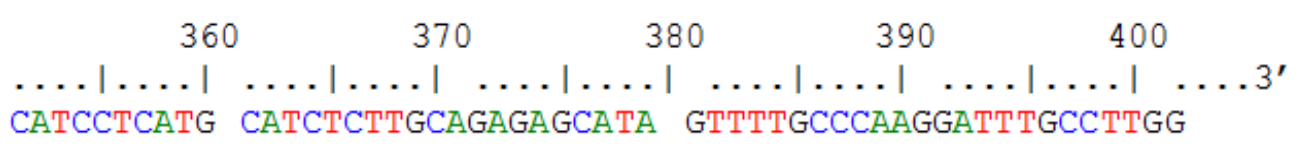

Figure 1. Partial sequence of AT3 gene from C. frutescens cv. Cakra Hijau that has been isolated

The DNA total was isolated from leaf by using the plant DNA isolation kit (Nucleospin ${ }^{\circledR}$ II, Macherey-Nagel, Germany). The primers used were 5'-ATG GCT TTT GCA TTA CCA TCA-3' (forward) and 5' -CCT TCA CAA TTA TTC GCC CA-3' (reverse). PCR cycle: $94^{\circ} \mathrm{C}$ for $5 \mathrm{~m}$ (pre denaturation), $94{ }^{\circ} \mathrm{C}$ for 1 minute (denaturation), $53{ }^{\circ} \mathrm{C}$ for 1 minute (annealing), $72^{\circ} \mathrm{C}$ for 2 minutes (extension), and $72{ }^{\circ} \mathrm{C}$ for 10 minutes (final extension) in 30 cycles.

The PCR products were electrophoresed by using $1 \%$ agarose gel and sequenced by Big Dye transiluminator through ABI 3130 Genetic analyzer machine at Eijkman Institute for Molecular Biology of Jakarta. The sequencing result was analyzed by using Bioedit, Peak trace, DNA Baser, $B L A S T$, and Clustal X software.

\section{RESULTS AND DISCUSSION}

The AT3 gene isolation from C. frutescens cv. Cakra Hijau using PCR technique with a pair of primersproduced 404 base pair fragments. The position of amplified target gene located in 1918$1434 \mathrm{bp}$, refer to AT3 of C. frutescens (access code: HM854860.1 and AY819026.1). Suspected AT3 gene sequence result from $C$. frutescens cv. Cakra Hijau are shown in Figure 1. The analyses sequence using BLAST program were compared with AT3 of C. frutescens cv. Shuanla (Figure 2A) and C. frutescens cv. BG2814.6 (Figure 2B). The result shows query coverage of $24 \%$ and $10 \%$, respectively, with similarity index $99 \%$ of each. According to the result, sequences that have been acquired are AT3 gene.

The DNA sequence from AT3 gene of $C$. frutescens cv. Cakra Hijau was analyzed by using ClustalX to make an alignment of amino acid with AT3 of C. frutescens cv. Shuanla and C. frutescens cv. BG2814.6. The amino acid alignment shows that $A T 3$ gene of $C$. frutescens cv. Cakra Hijau is located in amino acid the $43^{\text {rd }}$ to 139th of AT3 amino acid sequence of $C$. frutescens cv. Shuanla and C. frutescens cv. BG2814.6 (Figure 3).

We lack confidence to assure that the first methyonin in our amino acid sequence is a start codon, regarding that there are 42 amino acid upstream to ours started with methyonin that has not yet been isolated. Furthermore, there is another fragment downstream from amino acid $140^{\text {th }}$ that has not yet been obtained in our study. So far, there is no report for the exact length of AT3 gene from C. frutescens cv. Shuanla [15] which shows no stop codon in their reported AT3 sequence. 

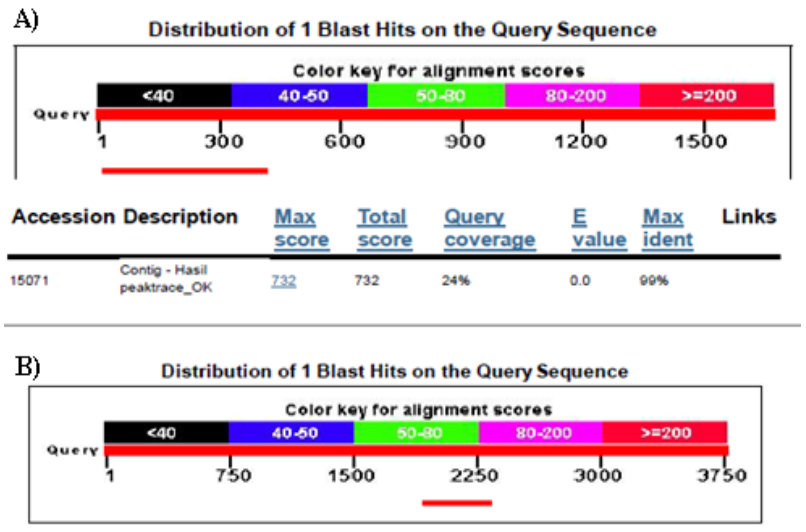

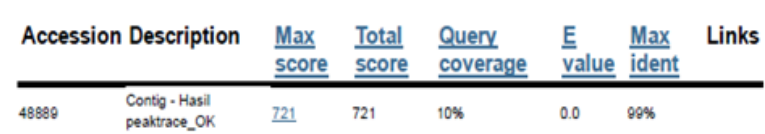

Figure 2. BLAST result of target gene compared with a) AT3 gene of $C$. frutescens cv. Shuanla, b) AT3 gene of $C$. frutescens cv. BG2814.6

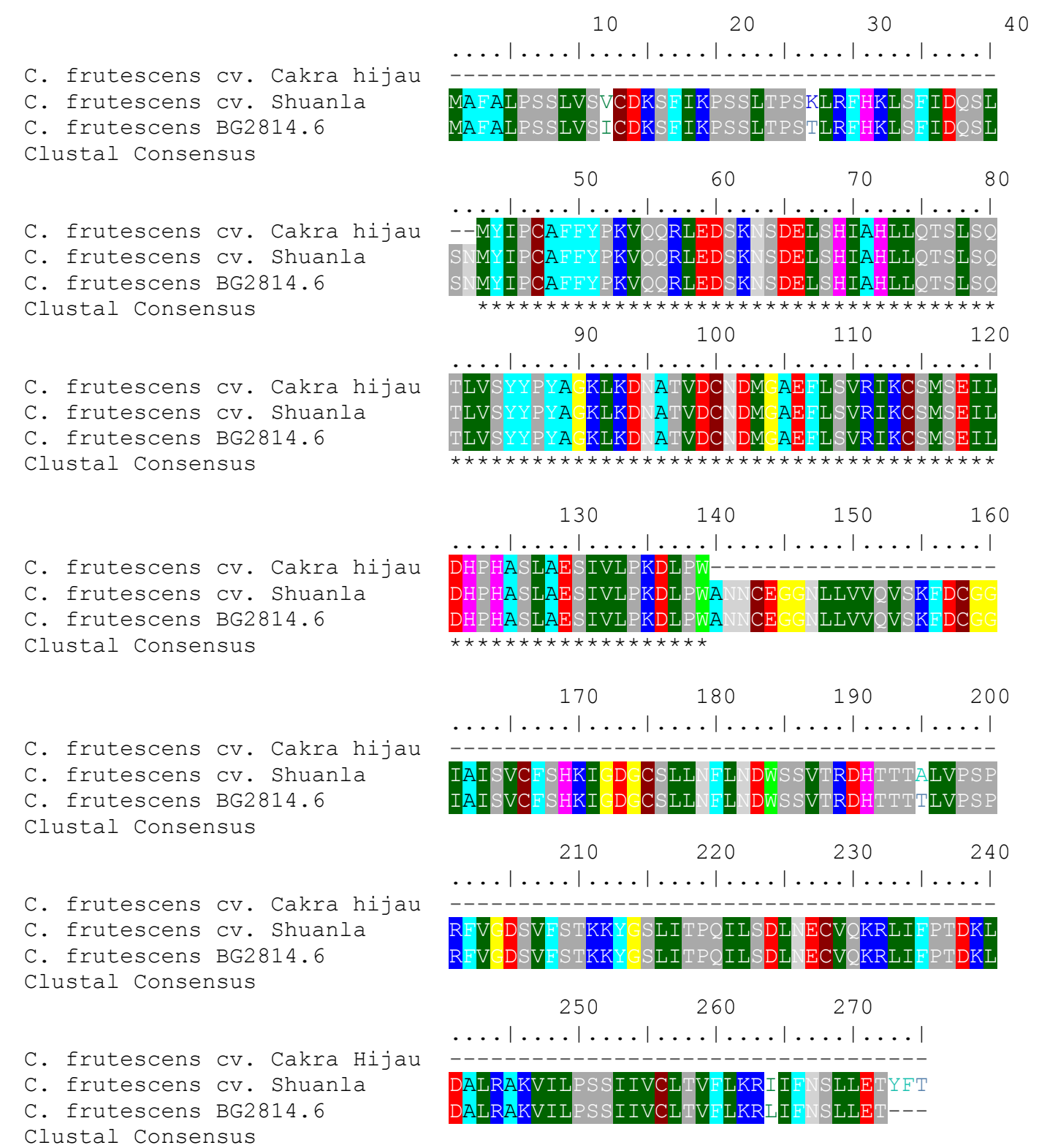

Figure 3. Amino acid alignment between AT3 from C. frutescens cv. Cakra hijau with AT3 from C. frutescens cv. Shuanla and C. frutescens cv. BG2814.6 


\section{CONCLUSION}

This study successfully isolates $404 \mathrm{bp}$ suspected fragment of AT3 gene from C. frutescens cv. Cakra Hijau which encodes 97 amino acids. The sequences obtained are the middle part of AT3 gene. The isolation of up-stream and down-stream part of this gene is necessary to obtain the intact sequence.

\section{REFERENCES}

1. Backer CA, Brink Jr BVD (1965) Flora of Java Vol II. N.V.P Noordhoff. Groningen.

2. Djarwaningsih, Tutie (2005) Capsicum spp. (cabai): Asal, persebaran, dan nilai ekonomi. Biodiversitas $6: 292-196$.

3. Sukrasno, Kusmadiyarni S, Tarini S, Sugiarso NC (1997) Kandungan kapsaisin dan dihidrokapsaisin pada berbagai buah Capsicum. JMS 2 : 28-34.

4. Rukmana R (2002) Usaha tani cabai rawit. Kanisius. Yogyakarta.

5. Mori A, Lehmann S, O’kelly J, Kumagai T, Desmond JC, Pervan M, McBride WH, Kizaki M, Koefler HP (2006) Capsaicin, a component of red peppers, inhibits the growth of androgenindependent, P53 mutant prostate cancer cells. Cancer Res. 66 (6): 3222-3229.

6. Lee YS, Nam DH, Kim JA (2000) Induction of apoptosis by capsaicin in A172 human glublastoma cells. Cancer Lett. 161 : 121-130.

7. Xu HK, Kim YC, Lee JW, Kim IS, Yoo KC, Higashio H (2002) Change of some constituents along with the fruit maturity in Capsicum species. Journal Kor. Soc. Hort. Sci. 43: 39-42.
8. Lee CJ, Yoo EY, Shin J, Lee J, Hwang HS, Kim BD (2005) Non-pungent Capsicum contain a deletion in the capsaicinoid synthetase gene, wich allow early detection of pungency with SCAR markers. Mol. Cells 19: 262-267.

9. Prasad NBC (2006) Characterization of capsaicin synthase and identification of its gene (Csy1) for pungency factor capsaicin in pepper. Proceedings of The National Academy of Science of the United States of America (PNAS) 103. Editor: Verma IM, Eisenberg R, Fersht A, Piperno DR, Snyder SH, Turner BL, Vogt PK, Warren ST, Weitz DA, Wessler SR. 13315-13320

10. Stewart C, Kang BC, Liu K, Mazourek M, Moore SL, Yoo EY, Kim BD, Paran I, Jahn MM (2005) The pun1 gene for pungency in pepper encodes a putative acyltransferase. The Plant Journal 42: 675-688.

11. Leung FW (2008) Capsaicin-sensitive intestinal mucosal afferent mechanism and body fat distribution. Life Sci. 83: 1-5.

12. Kim JS, Park M, Lee DJ, Kim BD (2009) Characterization of putative capsaicin synthase promoter activity. Mol. Cells. 28: 331-339.

13. Stewart C Jr, Mazourek M, Stellari GM, O'Connell M, Jahn M (2007) Genetic control of pungency in Capsicum chinense via the Pun1 locus. Journal of Experimental Botany 58: 979-991.

14. Lee JM, Nahm SH, Kim YM, Kim BD (2004) Characterization and molecular genetics mapping of microsatelite loci in pepper. Theor. Applied Genetics 108: 619-627

15. Deng MH, Wen JF, Zou XX, Zhu HS (2010) Clone and sequence analysis of acyltransferase (Pun1) gene in pepper. http://ncbi.nlm.nih.gov/. Accessed date: June 30, 2013. 